DOI https://doi.org/10.36059/978-966-397-110-0/2-20

\title{
THE INTEGRITY PHENOMENON IN SOCIAL EXISTENCE
}

\section{Tarasiuk L. S.}

\section{INTRODUCTION}

In the study proposed the theoretical interpretation of the integrity phenomenon in social existence is carried out. Studying the issue of the integrity of the personality is significant under the modern socio-cultural reality conditions, when the previous worldview ideals have lost their significance, and society has a huge need for new value orientations. The article reveals that the priority of values is determined by the human worldview culture. The thesis about the construction of the integrity as a necessary point of life changes is substantiated.

Analyzing the socio-cultural and philosophical-anthropological approach to the integrity, this phenomenon appears as one of the adaptation mechanisms in overcoming external and internal conflicts in a modern risk society. The integrity phenomenon can be defined as transformation of the personality, as an internal freedom of a person, valorizing a person over the phenomena of the material world existence. Integrity is a manifestation of harmony of human spiritual, mental and physical dimensions; harmonization of the personality of integrity combines all aspects of human existence, both external and internal, in the sense that a person has the opportunity to discover and express themselves at most, become themselves, and reveal their true inner self. The human integrity makes it possible to perceive value, uniqueness, individuality in another person, too. The main motive of the personal level of behavior is human dignity, as G. Pico della Mirandola stated uncompromisingly. The main motive of the characteristic level is the achievements of human activity, along with the methods of such achievements. These two motives are directly related to the nature of the relationship nature between people. It is an important feature of a mature person to recognize the unique value in the Other person, as well as to act in accordance with such calling. Not just the recognition of value of the Other person, but also the ability of productive relationship with them, expressed in mutual enrichment through the spiritual meaningfulness of each person is important. The 
main criterion for maturity of the personality is the acceptance of value of the personality in the Other person, the value of the Other person and the desire to create something together. A person with a holistic worldview will not deny the value of the Other person. Both meeting with the Other person and collaborating with them is an opportunity to renew their experience and recreate their integrity. Reproducing in the identity of the Other, a person finds their own uniqueness, and from there, they return to the Other and see them as more significant. Perhaps, one should consider the following: what a person generates in this world, what ideas, thoughts, feelings, actions, attitudes towards others, to the world. It is necessary to create a new meta-reality, to renew integrity in own existence, there is no sense to put efforts into a struggle, generated by distracting external and internal contradictions. After all, the only way to change your existence as well as your society is through rethinking and implementation of something that has been rethought. There is an axiom: you can not change the world without changing yourself.

The determination of the problem of the integrity of the personality takes place within the context of correlation between the whole and parts in three general approaches, namely holism, merism, rationalistic dialectics, or antinomianism. Therefore, elements of holism are revealed in the ancient philosophers - Milesians, Neoplatonists, in the Early Modern Age - in the philosophy of B. Spinoza, G. Leibniz. The Modern Age is characterized by the works of existentialists, personalists, and postmodernists. Merism is the area in which the whole is the total of elements. It is worth noting that numerous scientific studies reveal the nature of the integrity in general and the integrity of the personality as an individual category. Solving the problem of the human existence integrity makes it possible to determine the meaning and value of human life, making the universality and uniqueness of human nature and the essence of the inner world, as well as the mission of a person more transparent. However, integrity as an integrated entity combining the physical-mental and spiritual content of the personality and determining the peculiarities of their individual reflection of continuous transformations in accordance with the essential transformations of the world, the concept itself has to be well-described and studied. The analysis of these concepts shows that, studying a person as integrity, we can consider the existence of both a person in all their manifestations and the history of mankind as a whole in a new way. 
The existence is given to us only in the world and through the world - as humanization of existence, as the existence filled with the creative personality presence. Therefore, the level of a personality's worldview is essential. A worldview is an attempt to comprehend oneself and find their place in the world as a unity with other diverse worlds. This is an attempt not only for comprehension, but also for self-awareness. There is no such person who would not put a question sooner or later: who am I, what is my worldview, my existence, my life, and who am I as a personality. A person should have a goal and go for it. A person without any goal gets inactive that means the life without any sense and zest for life. A person should take responsibility for their "Self". "We" should be divided into separate "I" - otherwise nothing will happen. For action, for a shot, for a word, for a gesture - a separate "I" must be responsible, but not "We" in general. The integrity of the personality is in the fact that people treat themselves honestly and uncompromisingly, all their actions and thoughts - responsibly, which means that they are responsible in relation to other people. A person of integrity has a very responsible attitude to own life. Their goal-orientation is the very energy, the only and absolute spiritual driving force, capable of changing the vector of motion at the point of absolute nothing, thickened tartarus or absolute zero of the chaos emptiness, filling own existence with the meaning. This suggests that a person can go up to the light by the steps of self-consciousness and recover their holistic worldview through the goal and motivation.

\subsection{The Issue of Self-Fulfillment and Self-Identity of Personality}

Studying the issue of the integrity of the personality in the context of social philosophy, philosophical anthropology, philosophy of culture, one should turn to phenomenology, since the outlined tasks of the topic have definitely appeared in the world of human life. In phenomenology one of the key concepts is the category of the "life world". This concept describes the bonds of consciousness with the world which are formed in the field of human life and generate self-evident things. Self-evidence is the area of "well-known to all", "the circle of confidence", where things are treated with long-established trust and taken without the need for scientific substantiation. E. Husserl spoke about overcoming the crisis of European rationalism exactly by the development of the "science of spirit", which he called the science of the human world. The peak of the 
human development is their integrity, their holistic existence, with which such personality identifies themselves. A person of integrity is a person whose will, thoughts, actions are in harmonious correlation. In philosophical anthropology, psychology, psychoanalysis, the deep unity of a person with the true self, with another person or with people in general, reproduces the concept of "identity", which means from Latin identificare - to identify. A personality identifies themselves with something, having a standard to comply with; therefore, two important categories, such as "identification" or "self-identity", and "compliance" appear. Deepening the knowledge of these concepts and clarifying their essence, one can outline the vectors of gaining the personal integrity.

M. Heidegger in his work "The Identity and the Differentiation" interprets identity within the context of the unity of existence, which means the similarity of each existing thing to itself and to every other existing thing $^{l}$. In a range of the areas of philosophy and psychology, namely, in personalism, meta-anthropology, existentialism, existential psychology, existential psychoanalysis and androgen-analysis, the basis for identity is self-identity (self-similarity), the unity of a person with their existence and deep personal dimensions. Authenticity is interpreted here as perfection and perfect, as well as its simultaneous reflection in experience and thinking. In such context, F. Brentano's idea that identity is "a compliance that thinks in perfection" is quite interesting ${ }^{2}$. It can be noted that the identity of the personality of integrity is turning into self-identity more and more, that is, the measure of freedom is increasing in the choice and creation of the personal identity and the identity of other people.

Identity is a unity with the spiritual and psychological openness of own personality and associations of personalities that arise on the basis of common moral values, principles and the beauty of relationship. Any personality, reaching their integrity, reveals their true inner world. The essence of the personality is in their integrity, which appears in all the beauty of human existence and the creation of a new living space by a new person. The concept of "self-identity" leads us to the concepts, which are interconnected a lot, such as "gender identity", "national identity", "gendered identity", and "archetypes of culture".

Thus, a person should comply with, first of all, their own harmony, harmonious correlation between will, thoughts and actions. It is the will, a

\footnotetext{
${ }^{1}$ Гайдеггер, М.: Бытие и время. Статьи и выступления. Республика, Москва (1993).

2 Большой энциклопедический словарь: Норинт, Москва (1991).
} 
conscious striving for a goal achievement that transforms from the possibility to reality based on the energy of the unconscious. The comprehension of the phenomenon of freedom in human existence has undergone a complex evolution. According to the first one, the will is a conscious phenomenon, it is intelligent in nature. The brightest example of this paradigm is presented in German classical philosophy (I. Kant, F. Schelling, G. Hegel, F. Nietzsche). The second paradigm interprets the will as a phenomenon that surpasses consciousness and intelligence or it is the opposite of them. "The will stands above thinking", - D. Scott believed, and Ockham had the same attitude. The will can be opposed to instinct. If the instinct is an external active force, then the will is always the achievement of the individual himself. The concept of "will" is a synonymic concept with "freedom". In other words, the will can be understood as freedom, aimed at any goal. The will can be considered as the will to the family extension, to self-protection, power, knowledge, and creativity, the will to love and freedom. A person makes a choice according to their worldview, their level of consciousness, their thinking where the thoughts of a person may reach, in which depths. Human thoughts are a kind of "a product" of their mind. The mind is the human ability to understand and comprehend the world. The mind covers the ability to generalize, integrate, transcend, analyze, synthesize, create ideas, as well as the possibility of their linguistic articulation. The philosophical conceptualization of the mind is too diverse to understand the picture of the evolution of such synonymous concepts as "intelligence", "thinking", "mind". This is due to the paradoxical state of mind, which even has found the anti-intelligence of own actions in the present day. Sense is the intellectual potential of a person used for adaptation in the environment. In this sense, the degree of intelligence can be associated with the level of adaptation to the environment. Intelligence can be understood as the ability to process information, unlike erudition, which only means the availability of information in memory. First of all, intelligence can be associated with conceptual thinking. The intelligence operates with abstractions, trying to be distracted from feelings and values, the experiences of which leads to a figuratively-holistic vision of the world. C. G. Jung believed that in order to obtain a holistic picture of the world, the value aspect should also be mentioned. Therefore, the empirical cognition is essential; the intelligence escape from the sensual 
and the value-based things is an escape from holistic ones. This is integrity of human existence, a holistic striving of a person that defines the specifics and limits of the authenticity expression. To be yourself, to be true, to achieve your goal, to set new boundaries and reach them, is definitely a way to gain your own integrity. The consciousness, the worldview, the language, the word of the personality of the integrity can create a new world, create a new living space and experience the existence in full. If the integrity and expressiveness of thinking, as well as the language are broken, it means that the integrity of speakers is violated. The word must resonate with subconscious at the deep level, clear and, moreover, heal it, bring it into the state of harmony.

In a deep and more complete way one can study the category of the "integrity" in the context of meta-anthropology. S. Krylova studied the category of "wholeness", "integrity" and "goal-orientation"3. The integrity of existence means the correspondence of a person to their nature, mainly in the everyday dimension of existence. The integrity in a human existence is opposed to goal-orientation. If the integrity reflects the unity and self-identity of a human existence, then the goal-orientation expresses a certain vector nature.

A whole-hearted person is calm and complete, goal-oriented person is energetic and active, aimed at achieving the goals even in case of destruction of their own nature. Therefore, it is logical to assume that the integrity is a characteristic of a female principle with its striving to stability and constancy necessary for the birth and upbringing of a new life. At the same time, the integrity characterizes a male principle as well in the daily life dimension of human existence with its tactfulness, but not a strategic activity and goals assigned outside ${ }^{4}$.

Thus, entering the harmonious unity with goal-orientation, the integrity gives rise to the integrity of human existence.

Since we found out that the personality of the integrity is revealed exactly through creativity and creative work, one can identify the stages of the formation of a possible creativity: creativity realization, objectification, actualization and initiation. It is not enough to have a creative idea, but it must be realized, implemented in the area of human

\footnotetext{
${ }^{3}$ Крилова, С.А.: Краса людини. Особистість, сім’я, суспільство: Монографія. ТОВ «Видавництво «Аспект-Поліграф», Ніжин (2011), С. 396.

4 Тарасюк, Л.С.: Реалізація, об’єктивація, актуалізація та ініціація як етапи розгортання креативності в культурі. Гуманітарний часопис: Зб. наук. праць. ХАI, Харків. 1 (30), 64-69 (2012).
} 
life in the essential forms for society. The realization of creativity is the process of the idea initial embodiment in communicating with the Other. On the way of embodiment, the subject of creativity must overcome existential and communicative obstacles, so the realization of creativity requires a special creativity of conviction. This is the creativity of the outline and the prospect plan. The objectification of creativity is the process of the idea embodiment in one or another professional material, in an artifact, work (a monograph, a novel, a film, a sculpture, etc.), in something that is more often understood as creativity in the exact meaning of the word. There are an internal creative act and a creative product manifesting externally. It is essential to understand that the objectification has an ambivalent nature: it can be either a creative embodiment of an idea or its decline, its loss ${ }^{4}$. The actualization of creativity is the process of "existential revival" of the work and its author, overcoming the inherent collisions of the personality in the creative process. It is actualization of creativity that can prevent from the transformation of work into the object and the product, and the author - into the craftsman.

Therefore, actualization of creativity in some way opposes to objectification: if the objectification is the form, then the actualization is the meaning. "Actualization, - as V. Frankl mentions, - is the personalization of the world, its spiritualization and relaxation. Actualization as personalization has a hypothetical nature and is the end of existence. It awakens, constrains and develops freedom and love in existence of a man and a woman"5. The initiation of creativity is in the fact that the abilities are revealed in a particular person and special knowledge is given to them, leading to a greater degree of responsibility for own existence.

Such person experiences the mysterious, sacred power of creativity and creates; this is the very sense of sacredness in initiating the transformation of oneself and of own existence in culture. Therefore, the process of culture creation can be understood as a fundamental interaction of actualization and objectification. If the objectification is the form, then the actualization is the meaning. Actualization makes sense only when it comes to the Other or the personality. The deep meaning of creativity is revealed in the knowledge and creation of the Other. A person of integrity

\footnotetext{
${ }^{5}$ Франкл, В.: Человек в поисках смысла. Прогресс, Москва (1999), С. 67.
} 
constantly strives to the council with other personalities, to the co-creation of existence.

Creative work is a way up, this is a breakthrough to the new world; in the creative condition a person feels enthusiasm; the creative work should overcome substantiality of the world. Thus, the creator faces the world of objectification, and the results of creativity must become a part of the culture as an objectification system. This is one of the fundamental problems of creativity revealing the dramatic nature of creativity. The creativity of the true creator must change the world, and not overload it with new creations ${ }^{6}$. M. Berdyaev rightly notes that in a state of creativity a person is on a certain rise, striving not for the realization of a pragmatic goal, but for the manifestation and embodiment of their inspiration ${ }^{7}$. That is to say that a person of integrity can not keep everything inside, they must go beyond their own boundaries.

The philosophy, namely, social philosophy, philosophical anthropology, and the philosophy of culture must become the affirmative and dominant research of the integrity. The philosophers must personally educate themselves for holistic contemplation and experience, to clear and consolidate their obviousness, to check and confirm it, striving to accuracy of their contemplation, master their elements, giving flexibility to own perception, striving to perfection. All these imperatives require creativity from philosophers' side demanding to act according to their conscience, to form their spiritual nature in this relation.

The task is not easy, but its achievement is possible: to be - to act to philosophize. A person can think and study only freely, because true thinking is independent; and no scientific study can be developed under the plan or through the prohibition. The imposed way of thought kills thinking, and then only verbal visibility remains; that is why a person of thought recognizes the right of others to illusion or mistakes. Every creative work requires freedom - voluntary self-embedding, contemplative initiative, personal inspiration, and love for it. Creativity arises from the inner, unlimited, sacred motivation, which involves individual instinct and which is guided by the personal spirit. Human creative work arises from limitations and suffering, and every creation of

6 Тарасюк, Л.С.: Креативность. Философская антропология: международный словарь. Киев (2011), C. 178-183.

${ }^{7}$ Бердяев, Н.А.: Дух и реальность. Вступ. ст. и сост. В.Н. Калюжного. ООО «Издательство АСТ»; Харьков: «Фолио», Харьков (2003). 
culture is overcoming and designing human suffering. To create such overcoming, we have to accept our suffering, search for way out, clear and enlighten our hearts. No one can do it instead of us, and outside help can come only in the form of advice, but not in the form of an order or prohibition. There is no creativity without freedom; and someone who does not understand this, never creates anything and does not feel inspired: "A person can experience the act of conscience only freely: to open your heart, hear the inner call, accept it and prove it by action. This valuable act can be neither forbidden nor proposed. It is spiritual and holistic, to violate its freedom means to try and leave a person without conscience, and only a conscienceless person can do this" ${ }^{\prime 8}$. Freedom is an internal factor determining the degree of person's creative program completion.

Essential powers are the reference point of each personal activity and they reveal themselves as actions of spiritual powers. Such power appears due to the internal aspiration as the aspect of volition act. Not only creative activity but also: creative inspiration, cognitive search, confidence in intention, goal achievement, as well as total autism, aspectizing of new things, construction of dominant, mutual experience of events, catharsis of spiritual work ${ }^{8}$.

This is a special spiritual state that generates goals for combining its essence in external and internal concentration. In this state, a person begins to cognize their subjectivity: "I am a subject" from the natural origin of "I am an object" and to realize that it [a goal] is an object for self-disclosure and self-cognition, that a goal is for themselves, a goal in itself, a self-object for themselves. At such stage everyone in a state of spiritual aspiration is able to perceive other people as well: their thoughts, suggestions, views, ideas, to see other person as self-valuable, to understand their value. That is called patience, loyalty, sociability, ability to communicate, friendly understanding in social life. Spiritual tension of the personality creates a special field of interaction between people and internal interaction with themselves, the field as a state of awareness expanding the ability to "spiritual space"; spiritual space as a field of spiritual interaction is an individual space of the personality, in which they interact with themselves and other people in their consciousness. Spiritual space is the very individuality, indivisibility and spiritual

\footnotetext{
${ }^{8}$ Бердяев, Н.А.: Дух и реальность. Вступ. ст. и сост. В.Н. Калюжного. ООО «Издательство АСТ»; Харьков: «Фолио», Харьков (2003), С. 500-503.
} 
substance, which is experienced as a special inner essence. Spiritual space in a person is not so much for themselves, as for all, and it is not possible to appropriate "I" as your own.

Recognizing the spiritual essence as only your own, "I" is in an illusion. "I-myself" is the alienation of the spirit into possession, but this is impossible due to the infinite principle of the spiritual, which can not be the property of the finite; this is a manifestation of separating oneself according to the spiritual essence. It is impossible to use this spiritual power as an absolute power for self-affirmation on the Earth. This is "spiritual selfishness", in which people, who intend to use spiritual power for their personal purposes, often fell into.

The revelation of the human spiritual essence through creativity has the following manifestations: the space of human communication, mutual understanding on the basis of unified communicative principles, methods; this is a spiritual and communicative power which influence contributes to the emergence of an information society; value-based individualization leading to the historical cultural and value-based unity of people and their unification in historical time, in development and improvement. It establishes the value orientations of spiritual unity. "Value-based vision" of a person who is spiritually improving themselves, is transferred to all surrounding: "knowledge as a value", "human nature as a value", "animal world as a value", "socio-cultural norms as a value", "a person as a value". The society only helps a person to subjectify their socio-cultural objectivity, to reveal their individuality and individual spiritual essence, and to lay the basic grounds for their self-fulfillment, to actualize their abilities.

Creative work is the value-based power that bears the spirit, the true essence of a person. By the development of values one can distinguish between temporal changes in the spiritual space of a person. Value-based growth, personal and own potential are the concepts by which you can describe the aspiration of the mature person to sense. It is, as a rule, a process close to self-actualization of the personality or identical to it. The revealing of personal in a person contributes to the actualization of the process of self-development under certain conditions. It should be noted that there are features inherent in personal maturity; in this case, creativity is the ability to sensitive perception of disharmony, the creation of something new which has not existed before, a creative orientation. 
Synergetic nature, autonomy, sociability, self-perception, decentralization, responsibility, tolerance, depth of emotional experience - these are the features that are vivid signs of a self-actualizing personality, inherent in creativity. However, only with a sufficient degree of such features one can talk about the personal maturity. A personality who is self-actualizing not necessarily is mature as for personality. At the same time, together with that the actualization itself is both a sign and a process of crystallization of the features of the personal maturity, a cognitive aspiration for creative existence, that is, for the synthesis of existence and the activity, to the creative principle in the essence of the person in real existence and activity in culture. Creativity has something holy, sacred in its essence, something that makes it a completely new thing in the world; such "sacred uncovering" can be called "the initiation of creativity", something which appears in the world from the depths of the sacred. Initiation is the consecration, the mystery of such knowledge, laws that give a person a special understanding of responsibility for their existence.

To better understand the meaning of the sacred, holiness, one should recall the above definition of the Spirit and the Soul. As the spirit we understand the ability to a creative breakthrough and, the breakthrough itself; under the soul - the ability to love and suffer, as well as their existence. It will be correct to determine holiness as the power of the human soul over own spirit and body. Holiness is the power of love and non-violence against evil, which manifests itself in personal lives; this is the power of the example and the action. To the extent that the qualities of the soul (aspiration for love, tenderness, tolerance) are inherent in the female principle, cleared from its empirical manifestations, to the same extent we can call holiness as the female principle in its highest sense. Holiness as warm-heartedness combines the spirit and the substance, removing their tragic opposite. Holiness is in the fact that the particular person is open to knowledge that is closed from the others; and this is the essence of the priesthood, sacredness, and mysteriousness.

Due to the free aspiration for creativity, creative work, the will is not subject to social sanctions and is not eliminated by the order. In social self-fulfillment one can find freedom, if it corresponds to the world of selfcognition of the spiritual essence of the person; it is superior to all human laws and obeys only the laws of universal existence. Subjective selffulfillment of the person takes place when it is a goal of self-improvement 
of the object, when the full self-determination of the spiritual principle is taking place in it through the individual of the human subject ${ }^{9}$.

Self-fulfillment on the formation of the spiritual essence of a person is significantly different from the vision of everyday and practical ways of self-improvement; it goes beyond the limits of physical definition to the individual area of a person: these are the subtle substances that have to be cognized. The path to spiritual self-fulfillment was laid by a great number of philosophers and thinkers. Spiritual self-fulfillment is not very complex as propaedeutics: self-improvement in creative activity, individual responsibility for spiritual and value-based determination, self-education, self-regulation of own life path, development of individual existence culture as lively culture existence - all this is a continuous process of the spiritual work - actualization and fulfillment of person's creativity'.

\subsection{The Creation of the New Life Space}

Revealing the integrity phenomenon as a new living space creation, it is worth drawing attention to the potential of human opportunities. After all, creating a new living space is possible in the event that the person is realized in full, can reveal their potential opportunities to integrity, perfection, and completion. Potentiality is the ability of the human way of life. Analyzing the teachings of the Ukrainian philosopher G. Skovoroda, we can mention "integrity" as "connection" with ourselves and the world around us. It is rather important to substantiate such categories as intentionality and potentiality, which occupy an important place in the creative fulfillment of the personality, and hence, in the integrity of human existence. Intentionality and potentiality are the essence of the ontological abilities of the existence of being, which runs through the existence in general and every form separately.

Intentionality and potentiality can be defined as internal, deep conditions of the uncovering of existence, reality, the world, and the essence of the existing. One can consider the concept of intentionality and potentiality through dialectical categories of opportunity and reality. Potentiality can be defined only as the intentional ability of existence the act and the process of the existence of being (interaction, change and formation), directed and goal-oriented to development. The intentionality

9 Тарасюк, Л.С.: Право на цілісність і право бути собою. Друга всеукраїнська наукова конференція «Актуальні проблеми розвитку освіти і науки в умовах глобалізації», м. Дніпро, 28-29 жовтня 2016. 2016, С. 42-44. 
of individual existence is expressed in the uncovering of the essential characteristics of the human way of existence as such in the reality of a person's individual life.

Potentiality of individual existence is determined by its unique, individual essence of an independent existence. Therefore, potentiality is a significant feature of extraordinary self-existence. Beyond the limits of creativity there is no personality, therefore, it is through their creative potential that a person reveals and fulfils themselves. M. Berdyaev wrote that creative morality is not the execution of the law; it is the revelation of the person. Spirituality is related to humanity. The spirituality manifests itself in the act of saturation of every moment with value-based meaning by a person in the human existence. The value is the creation of the human spirit. The phenomenon of existence, which becomes the subject of value, is "spiritualized" by the human essence that gave rise to this value. The intention of the existing is given in the issue of correlation of the possible and the real, the actual and the potential. Humanity is the unity that reveals itself in a human way, which puts everything that exists in itself, and reveals it in the formation of itself. The unity is also inherent in the ultimate goal of revealing itself, because it is infinite; accordingly, there is no other end goal in the creative activity of a person, except for the person. V. Solovyov noted: "A human personality is an opportunity for fulfillment of unlimited reality" 10 . The culmination of the process of subjectivity of the personality is the complete, holistic "world of the individual "I" of the personality", which by its self-development becomes the meaning of cultural-historical content. "The world" is the organized whole, in which the components are mutually dependent and mutually developing in their self-determination and self-development.

The essence is the internal basis for determination of the single existing, from which, by correlation with the change of conditions, all changes can be deduced. The essence can appear simultaneously as a conclusion of the past development and as an opportunity for further development. Thus, the essence appears as an indirect link between the existing at different stages of the formation process. The essence, thus, appears as a unity of the possible and the real. The existence acts as a causality in relation to itself.

\footnotetext{
${ }^{10}$ Соловьев, В.: Философское начало цельного знания. Харвест, Минск (1999), С. 49.
} 
The action of reason in itself is an internal movement of reason, aimed at preserving the reason as a qualitative certainty, stability.

Based on the above mentioned, one can note integrity as a balance between the external and internal world of a person, the balance in communication, in relationship. Every crisis in society requires rethinking and awareness of each person of their existence, the essence of their inner world. The phenomenon of human integrity and their existence is the basis of a new consciousness, a new personality, and creation of a new human life space. Every person has the right to this - the right to the integrity of the personality.

Critical times always, in one way or another, are accompanied by revolutionary changes in the spirit field; the former values are subjected to a devastating attack of rethinking and reinterpretation.

In relation to this, the world of Postmodernity is a quite special phenomenon. It is special in the sense that the history never knew such explicit and vivid explications of a new vision and a new understanding of the world, and at the same time such a radical denial of all past achievements and constants. The boundaries are blurred, and things, which may have seemed wild and unrealistic, nowadays become an everyday reality. Last but not least, it concerns the integrity phenomenon, androgynism, a gender component of human existence, where today, as never before, there is a total gnoseological, ontological, anthropological uncertainty; gender affiliation is no longer regarded as a kind of originally and permanently unchanged fact of life; borders of a gender are erased, mixed, and the whole world has already become like a gigantic medieval alchemical laboratory, but they are looking not for gold, which is not a philosophical stone, but a new person. In philosophy, art, such as painting, literature, music (enough to mention Sopor Aetemus, London After Midnight, Marilyn Manson), - in these or other youth movements and subcultures, the eternal dream of mankind for the creation of the first person-androgen is more and more often reproduced. It is necessary to study the phenomenon of the integrity of the personality within the philosophical anthropology, philosophy of culture, social philosophy, meta-anthropology, which offers consideration on the basis of the higher values of human existence: love, freedom, and creativity. Such studies are significant for the understanding and rethinking of the integrity of the personality, the essence of a person, their purpose, existence, a morally 
new person with the priority of value-based thinking, the highest values of human existence.

\subsection{The Influence of a Person of Integrity on the Outside World}

The principle of integrity in social life, discovered and fostered by S. Frank, can become a real alternative to the transitional state of the social and individual consciousness, often denoted by such concepts as "crisis", "chaos" in modern science. S. Frank sees in a person a supreme goal and opposes to the disharmony the search for the human spiritual core, through which one can return the lost unity of the personality. A personality of integrity is capable of transforming chaotic space into orderly matter. This traces the processes of change, transformation, harmony, creative work, when the birth of a new energy comes from the transformation of chaos. A personality of integrity influences the surrounding space in a constructive way, as well as everything that the person interacts with. Russian scientist I. Kireevsky realizes the principle of integrity as "the main dignity of mind and character". At the same time, another scholar V. Zhukov contrasts the concept of "integrity" and "wholeness" and justifies the latter as a specific feature of "spiritual thinking". V. Zenkovsky calls integrity "the main inspiration of philosophical thought". Analyzing the works of B. Emelyanov, one can explain the idea of the integrity of the human spiritual life through the inherence of the moral principles and emotional life of a person, representing their inner essence. At the same time, well-known philosophers M. Berdyaev, S. Frank, P. Florensky, V. Solovyov, M. Los'ky, A. Khomyakov at al. emphasized that the integrity is mystical, it mysteriously contains in itself and not only keeps, but also exceeds the opposite of light and darkness, good and evil. According to S. Frank, a person and their relationship with the Absolute is, indeed, the supreme subject of philosophy. In the light of the integrity problem in its metaphysical system, the main anthropological issues are solved: the essence of a person, the meaning of human existence, the content of the concept of "personality", their relationship with society, etc. According to the thinker, "integrity is not a mere mechanical addition, but contains the objective foundations for the establishment of the human personality in a transcendent, outside 
the empirical, reality that is creative and embodies the human essence in a person" $"$.

The problem of human existence is connected with the problem of evil. Evil arises from the destruction of the primary integrity, that is, the separation of the individual essence from universal unity, when the basis of its reality becomes its own, isolated from the whole, center. However, evil can not destroy the universal existence, because the split exists only in a person, which separates them from spirituality, the Absolute, God.

People's search for the meaning of their existence is to find themselves, to return the lost integrity, that is, an attempt to find that original integrity of existence, which is expressed in the inseparability from the Creator. As S. Frank notes, "To find God in ourselves is an attempt to find own self by a person"12.

A person of integrity does not suffer; they can treat others with compassion, because their consciousness is in the plan of universal unity and council, in the plane of existence, where all the fragments are united into one single entire system.

\section{CONCLUSIONS}

Integrity is an integral institution, uniting physical-mental-spiritual content of the personality and defining peculiarities of their individual reflection of continuous transformations in compliance with essential transformations of the world. The diversity of the approach to this problem gives a fairly complete expression of the very essence of the integrity of human existence. The solution of this problem allows us to determine the meaning and value of human life, to enhance the universality and uniqueness of human nature and the essence of the inner world, the role of a person. Of course, it is necessary to study this category not only as a category, but actually as the human existence, because in the process of forming the integrity, a person experiences a lot of different collisions. It is awareness that provides an opportunity to reach a more qualitative level of your existence. The value-based aspect is crucial in the formation of a holistic worldview. A particular relation appears: maturity -value - co-creation - integrity, which is the basis for the formation of a holistic worldview. It provides an opportunity to

\footnotetext{
11 Франк, С.Л.: Реальность и человек: метафизика человеческого бытия. Белорусская Православная Церковь, Минск (2009), С. 287.

12 Франкл, В.: Воля к смыслу. Прогресс, Москва (2000), С. 37.
} 
embody new creative ideas, create new artifacts, meanings in the sociocultural space of human existence. A person should realize the importance of recreation of their integrity and enrichment of their inner world and the surrounding space in which they exist.

Self-fulfillment of a person of integrity is the most completed revealing of the abilities of talents and potentials of the personality in the physical, moral, intellectual, mental and spiritual aspects. The processes of goal-oriented self-fulfillment of a person are revealed in various areas and at different stages of their life. Therefore, one of the main human problems among others has been and is the problem of self-improvement of the personality, their spiritual evolution. The full revealing of the abilities of talents and potentials is reproduction of the integrity of the personality.

The integrity of the personality is the acquisition of fullness of all qualities, their revealing and realization. Any personality, reaching their integrity, reveals their true inner world. The essence of the personality is in their integrity, which appears in all the beauty of human existence and the creation of a new living space by a new person. The concept of "selfidentity" leads us to the very interconnected concepts such as "gender identity", "national identity", "gendered identity", "archetypes of culture".

Present challenges under the conditions of globalization bring a number of urgent topics and the need to study them, one of which is the following: existential dimensions of a worldview. Through cognition and creativity, every person can create their own inner world, as well as the world of relationship with Others. The human world is a combination of different personalities and worlds; the world can be defined as the result of the meeting of a person and existence.

Consequently, under the conditions of globalization, each person has to evolve, respond internally to the changes, taking place in the modern world, create new creative programs, implement them in their daily life activity, and transform their personal space and space of others into the best, integral and valuable. Integrity is an innate and acquired feature that finds answers to existential questions. Its social nature has a flexible dynamic effective orientation, that is, it perceives itself as the embodiment of its own powers-abilities that are freely implemented. Integrity has been never finally achieved, but it is both the real and the potential. A personality of integrity is goal-oriented and flexible, carries hidden 
energies, potentials that are becoming more and more revealing through the act of convergence with the world. Thus, one can speak of the integrity as self-revealing of the personality - their complete selfrevealing, as well as the social realization and filling of the personal existence and the existence of others with supreme spiritual senses.

\section{REFERENCES}

1. Гайдеггер, М.: Бытие и время. Статьи и выступления. Республика, Москва (1993).

2. Большой энциклопедический словарь.: Норинт, Москва (1991).

3. Бердяев, Н.А.: Дух и реальность. Вступ. ст. и сост. В.Н. Калюжного. ООО «Издательство АСТ»; Харьков: «Фолио», Харьков (2003).

4. Крилова, С.А.: Краса людини. Особистість, сім'я, суспільство: Монографія. ТОВ «Видавництво «Аспект-Поліграф», Ніжин (2011).

5. Соловьев, В.: Смысл любви. Философия искусства и литературная критика. Москва (1991).

6. Соловьев, В.: Философское начало цельного знания. Харвест, Минск (1999).

7. Тарасюк, Л.С.: Реалізація, об’єктивація, актуалізація та ініціація як етапи розгортання креативності в культурі. Гуманітарний часопис: Зб. наук. праць. ХАI, Харків. 1 (30), 64-69 (2012).

8. Тарасюк, Л.С.: Право на цілісність і право бути собою. Друга всеукраїнська наукова конференція «Актуальні проблеми розвитку освіти і науки в умовах глобалізації», м. Дніпро, 28-29 жовтня 2016. 2016, C. 42-44.

9. Тарасюк, Л.С.: Креативность. Философская антропология: международный словарь. Киев (2011).

10. Франк, С.Л.: Реальность и человек: метафизика человеческого бытия. Белорусская Православная Церковь, Минск (2009).

11. Франк, С.Л.: Душа человека. Предмет знання. Душа человека. АСТ: Харвест, Минск (2000).

12. Франкл, В.: Воля к смыслу. Прогресс, Москва (2000).

13. Франкл, В.: Человек в поисках смысла. Прогресс, Москва (1999). 
14. Breuer, S.: Adorno's Anthropology. Telos. 64, 15-31 (1985).

15. Briel, H.-M.: Adorno und Derrida, oder Wo liegt das Ende der Moderne? Holger Mathias Briel. N.Y.; Berlin; Bern; Frankfurt am Main; Wien: Peter Lang, Paris (1993).

16. Luckman, Th.: Das Problem der Religion in der modernen Gesellschaft. .Freiburg (1963).

17. Wellmer, A.: Zur Dialektik von Moderne und Postmoderne: Vernunftkritik nach Adorno. Suhrkamp Verlag, Frankfurt am Main (1985).

18. Zenck, M.: Kunst als begrifflose Erkenntnis. Zum Kunstbegriff der asthetischen Theorie Theodor W. Adornos. Wilhelm Fink Verlag, Munchen (1977).

\section{SUMMARY}

The article reveals the principle of integrity in social existence. The integrity phenomenon as the creation of a new living space is studied. It is proved that the human integrity is deeply associated with revealing of their qualities and their realization. In open, democratic society the integrity of the personality is expressed through communication with the Other as well as the phenomenon of socio-cultural partnership. The results of scientific research make it possible to introduce a new philosophical approach in comprehending the concept of the integrity as a socio-cultural problem and expanding the range of research, the subject of which becomes a person, restoring the integrity in dimensions of existence. As a result of theoretical searches, conclusions and provisions have been obtained with a practical value for self-revealing of the integrity of the personality. They can be recommended for developing strategies in the formation of civil society as well as institutes of both social partnership and social responsibility in Ukraine.

\section{Information about the author:} Tarasiuk L. S.

Doctor of Philosophical Sciences, Assistant Professor, Assistant Professor at the Department of Philosophy and History

V. I. Vernadsky Taurida National University, 33, Ivana Kudri str., Kyiv, Ukraine. 